\title{
LEXICAL COHESION IN JOHN CHEEVER'S SHORT STORY THE FIVE FORTY- EIGHT: A SYSTEMIC FUNCTIONAL GRAMMAR PERSPECTIVE
}

\author{
Alya Sabila Kusumanegara ${ }^{1 *}$, Lalu Muhaimi ${ }^{2}$, Husnul Lail ${ }^{3}$ \\ University of Mataram \\ *e-mail: alya.sabila05@gmail.com
}

\begin{abstract}
The objectives of this research are: 1) to identify and describe the use of the item of lexical cohesion devices in John Cheever's short story The Five Forty-Eight and; 2) to explain lexical cohesive devices contribute to building up coherence of language expression in the short story. This study focuses on Halliday and Hasan types of lexical cohesion, they are: Repetition, Synonym, Superordinate, General Word, and Collocation. Then the data were analyzed using descriptive qualitative method, and the source of the data is The Five Forty-Eight story text. The documentation study method has been used to collect the data from the short story. The analysis result shows that all the types of lexical cohesion were found in the story, there are: repetition $(58,8 \%)$, synonym $(7,4 \%)$, superordinate $(5,5 \%)$, general word $(17,1 \%)$, and collocation $(11,1 \%)$. This study finds out that repetition, general word and collocation are the most frequently types used in the short story.
\end{abstract}

Keywords: Lexical Cohesion, Unity, Coherence, Short story.

\section{INTRODUCTION}

Cohesion in discourse is defined as the cohesion of forms that structurally form a syntactic bond. Good and complete discourse requires cohesive sentences. The concept of cohesion refers to the relationship of forms which means that the elements of discourse (words or sentences) used to construct a discourse have a solid and complete relationship. In other words, cohesion is included in the internal aspects of the structure of discourse. In this regard, Tarigan (1987) suggests that research on the element of cohesion is part of the study of the formal aspects of language.

Cohesion is not only concerned with grammar, but also with vocabulary. Therefore, it is divided into grammatical and lexical cohesion. Halliday and Hasan (1976) classified the categories of Grammatical cohesion into four types: reference, substitution, ellipsis, and conjunction. and Lexical into two types: repetition and collocation. However, this study only focuses on lexical cohesion because it contributes to the creation of a coherent text. It provides a relationship between words or sentences in the text so that the reader or listener can easily understand the content of the text.

Discussing lexical cohesion is interesting, particularly to analyze lexical cohesion as a textual signal for coherence in fictional narrative texts such as short stories. Because cohesion shows the relationship from one word to another to make text cohesive, thus, the more difficult the text is to understand, the more difficult it is to convey the message in it. So, for the message in the short story to be conveyed clearly, it must be cohesive. The role of lexical cohesion in a text such as those used in a short story helps the reader understand the storyline.

Analyzing a discourse is not as simple as we think. The complexity of a text makes us have to analyze as well as possible, so that what is meant in the text can be understood and meaningful. Sometimes the discourse that we understand does not actually necessarily have meaning in it, and vice versa, meaningful discourse may not be easily understood.

The purpose of this research is to help students, especially students of English and linguistics to be able to 
understand how to analyze a discourse, especially an English one. In this case, is the element of cohesion and coherence in the English text. So that students are expected to be able to understand a readable and meaningful text.

\section{Data Source}

In this case, the short story to be analyzed comes from the prolific writer John Cheever, namely The Five-Forty Eight. This is one of the best short stories in the anthology The Stories of John Cheever. This story has a mixed plot, which begins with the climax of the story, then flashback in time and ends with the completion of the story.

\section{Data}

The data of this study, in the form of words, phrases, clauses and sentences, will be derived from a short story entitled The Five Forty-Eight which was published on April 10 ${ }^{\text {th, }} 1954$ in The New Yorker. This short story was published in a compilation of short stories of John Cheever. The focus of this study is not only on the aspect of lexical cohesion but also includes the usage based on systemic functional grammar perspective.

\section{Method of Collecting Data}

The method that will be used to collect the data in this study is documentation study. This method will be applied following the procedures of collecting the data as there are introduced and developed by Bowen (2009) involving several processes; skimming (superficial examination), reading (thorough examination), and interpretation. The practical steps of collecting the data of the study include:

1. Rendering the text into clauses

2. Identifying lexical cohesive devices in the rendered clauses

3. Reducing the data by narrowing the scope of classification into lexical cohesion

\section{Method of Analysing Data}

The steps of analyzing the data which have been collected from the short story text The Five Forty-Eight. If the data is examined more deeply in terms of structures of the sentences, it will be seen that the sentences are formed from a combination of words, phrases, clauses, and language expressions. After the raw data are collected, they will be reclassified into a narrower scope, namely cohesive devices, and finally lexical cohesion.

In this case, the method that will be used to analyse the data is content analysis, as it is developed and applied by Weber (1990). Content analysis is a method of analyzing the data that is an in-depth analysis of the contents of the written or printed information.

The data will be analyzed to identify lexical cohesive devices and explain their role in creating coherence. In this study, the data that have been rendered into clauses will be organized in several practical steps to ease the analysis.

The practical steps of analyzing the data of the study include:

1. Tabulation

2. Decoding each type of lexical cohesive device in accordance with its contribution to establishing coherence

3. Analyzing and describing the use of each type of lexical cohesive devices

\section{RESULTS AND DISCUSSION}

The data that have been collected from the story text are in the form of clauses. There are 171 clauses found which contained 318 lexical words and 145 grammatical words. Lexical words consist of nouns, verbs, adjectives and adverbs. Meanwhile grammatical words consist of pronouns, determiners, conjunctions, and prepositions. And based from the data, it is found that all the types of lexical cohesion are contained in the data. 
Table 1. The frequencies of occurrence of lexical cohesion

\begin{tabular}{|c|c|c|}
\hline $\begin{array}{c}\text { Types of Lexical } \\
\text { Cohesion }\end{array}$ & Elements & Frequency \\
\hline \multirow{8}{*}{ Repetition } & 1) epizeuxis & 33 \\
\hline & 2) tautatoes & - \\
\hline & 3) anaphora & 47 \\
\hline & 4) epiphora & 3 \\
\hline & 5) simploke & 21 \\
\hline & 6) mesodiplosis & 18 \\
\hline & 7) epanalepsis & - \\
\hline & 8) anadiplosis & 6 \\
\hline \multirow{3}{*}{ Synonym } & $\begin{array}{l}\text { 1) } \\
\text { idiographic }\end{array}$ & 2 \\
\hline & 2) contextual & 14 \\
\hline & 3) total & - \\
\hline \multirow{3}{*}{ Superordinate } & 1) superordinate & 2 \\
\hline & 2) subordinate & 1 \\
\hline & 3) basic level & 1 \\
\hline General Word & - & 37 \\
\hline \multirow{6}{*}{ Collocation } & 1) $\operatorname{adj}+$ noun & 6 \\
\hline & $\begin{array}{l}\text { 2) noun }+ \text { verb/ } \\
\text { verb }+ \text { noun }\end{array}$ & 2 \\
\hline & 3) noun + noun & 4 \\
\hline & $\begin{array}{l}\text { 4) } \mathrm{v}+\text { expression } \\
\text { with preposition }\end{array}$ & 4 \\
\hline & 5) verb $+a d v$ & 2 \\
\hline & 6) $a d v+a d j$ & - \\
\hline \multicolumn{2}{|c|}{ Total } & 216 \\
\hline
\end{tabular}

In Table 1 show that the number of words of lexical cohesion devices used in the short story is 216. And the amount of data from each device is different which are repetition with 127 data, synonym with 16 data, superordinate with 12 data, general word with 37 data and collocation with 24 data. This also can be seen that there are three types of lexical cohesion devices that the author frequently used in the story: those are repetition (epizeuxis a.k.a palilogia, anaphora, epiphora, simploke a.k.a epimone, mesodiplosis and anadiplosis with 127 data), general word with 37 data and collocation (adjective+noun, noun+verb/verb+noun, noun+noun, verb+expression with preposition and verb+adverb with 24 data). Meanwhile the two lowest data are synonym (idiographic/relative, contextual and total synonym with 16 data) and the last is superordinate (superordinate, subordinate and basic level with 12 data).
These results of analysis indicate that in the story, the author mainly used repetition to emphasize setting, highlight a character trait, and draw attention to a seemingly minor detail. The author also frequenly used general word in the story which means that he composed paragraphs cohesively by pressuposing word to another word that has the same reference in order to make the story cohesive. And the last highest frequency is collocation with 24 data, the author used collocation to make story seems more idiomatic.

In addition, the first lowest frequency is synonym, this indicates that the author did not use much more words to make story text more captivating. And to create more intriguing image in readers mind. Second lowest frequency is superordinate with 12 data, which indicates that in the story, there is not much word class that can be identified.

\section{Discussion}

According to Halliday and Hasan (1976), Lexical Cohesion is classified into two types; namely Reiteration (Repetition, Synonym, Superordinate, General Word and Collocation). Based on the data found, all of those types of lexical cohesion are used in the short story. And looking at the analysis method that has been used, which is content analysis, it is found that apart from those types, there are also several elements in each of them.

\section{Repetition}

Repetition is a repeat of sound, syllable, word, or part of sentence that are considered important to emphasize the appropriate context. And according to Keraf (2006), Repetition is classified into 8 types which are (a) epizeuksis, (b) tautotes, (c) anafora, (d) epistrofa, (e) simploke, (f) mesodiplosis, (g) epanalepsis and (h) anadiplosis. Based on the data, the frequency of Repetition is 127 words in which all the repetition types were found except for Tautatoes and Epanalepsis. 


\section{a. Epizeuxis}

This repetition repeats the words that are considered important.

For example:

(1) and he heard her screaming at him, "Kneel down! Kneel down! Do what I say. Kneel down!" (P. 38/CL. 155)

There is a repetition of epizeuxis, where the female character repeats one phrase Kneel Down! in a row as a command

\section{b. Anaphora}

Anaphora is the repetition of the first word or phrase in each line or sentence.

For example:

(2) The noise of a train coming down from the north drowned out her voice, but she went on talking. The noise filled his ears, and the windows where people ate, drank, slept, and read flew past. The noise grew distant.. (P. 38/ CL. $152,153 \&$ 154)

In the sentence above, the repeated words are The Noise at the beginning of each sentence, which emphasizes the noise of the train.

\section{c. Ephipora}

This is the opposite of anaphora, which is the repetition of the last word or phrase in each line or sentence.

For example:

(3) Her hair was dark, her eyes were dark; she left with him a pleasant impression of darkness. (P. 6/ CL. 46, $47 \& 48)$

The repeated words Dark at the end of each sentence, emphasizes the 'Dark' impression he felt about her.

\section{d. Simploke a.k.a Epimone}

Simploke is a repetition figure that combines the concepts of anaphora and epistropha. And is repeating phrase in order to emphasize a point.

For example:

(4) she said, "I haven't gone out for two weeks. I haven't had any work for three months. I haven't spoken to anybody but the landlady.." (P. 29/ CL. $120,121 \& 122$ )

It can be seen from the dialogue above, that the repetition of the word $\mathbf{I}$ haven't emphasized that she hasn't done anything for a while.

\section{e. Mesodiplosis}

A bit different from the previous anaphora and epiphora, this repetition is the repetition of a word or phrase in the middle of a line or sentence.

For example:

(5) Blake saw him go as if they had some reason to say goodbye - not as we say goodbye to friends after a party but as we say goodbye when we are faced with an inexorable and unwanted parting of the spirit and the heart. (P. 35/ CL. 146, 147 \& 148)

\section{f. Anadiplosis}

Repeating the last word in a clause into the first word in the next sentence with the aim to help emphasize the relationship between two ideas.

For example:

(6) "Oh, I know what you're thinking," she said. "You're thinking that I'm crazy, and I have been very sick again but I'm going to be better." (P. 26/ CL. $105 \&$ 106)

The relationship between the two ideas above is the woman's assumption on what the man thinking about her current situation.

\section{Synonym}

Types of Synonyms include (a) idiographic/relative synonym, (b) stylistic synonym, (c) contextual synonym and (d) total synonym. This type of lexical cohesive device is used to help improve the quality of writing by providing readers with a crisp and unique outlook of a text. Frequency of synonym is 16 words with idiographic and contextual synonym were 
appeared in the data. Meanwhile sylistic and total synonym were not found.

a. Contextual Synonym

This type of synonym has the same meaning, but only based on the context in which they are used.

For example:

(7) When he put on his clothes again, an hour or so later, she was weeping. As he was dressing, he noticed on the dresser a note she had written to a cleaning woman. (P. 9/CL. 53\&54)

Put on clothes and Dressing - in certain contexts, these are synonyms because they mean the same thing, but they won't always be classed as synonyms because they won't always be interchangeable. Telling someone to put on clothes and dressing mean the same thing when it involves with clothes, so they are contextual synonyms. But if you tell someone to buy you an antiseptic dressing, then replacing dressing with put on clothes wouldn't make sense. In this context, they aren't synonyms.

b. Idiographic/Relative Synonym

(8) He picked up the letter from the seat where she had put it. The cheap paper felt abhorrent and filthy to his fingers. (P. 30/CL.126)

These synonyms abhorrent and filthy both describe disgust. They mean the same thing, but describe slightly different degrees.

\section{Superordinate}

Superordinate categories are found at the top of a folk taxonomy. They display a high degree of generality and provide only very abstract information, which are sometimes called category-wide attributes. Therefore, according to Croft and Cruse (2004), class inclusion and degree of specificity manifest themselves in three levels of categorization - namely (a) superordinate level, (b) basic level and (c) subordinate level.

Basic level has the most basic cognitive functions. While Subordinate level display low degree of generality and class inclusion. It has clearly identifiable and highly detailed gestalts as well as numerous individuating specific features. And as the data found in the short story, the occurrence of item Superordinate found is 5 , with all the 3 category class levels contained in it.

a. Superordinate - Basic Level

For example:

(9) He ordered a Gibson and shouldered his way in between two other men at the bar, so that if she should be watching from the window she would lose sight of him. The place was crowded with commuters putting down a drink before the ride home. (P. 5/CL.36 \& 37)

Between the bar and the place there is a superordinate level (the place) and basic level (the bar) relationship. However, subordinate level was not found, because there is no stated about what type of bar is that.

c. Superordinate-Subordinate

For example:

(10) "If you really want a drink," she said, "I have some whiskey at my place." (P. 7/CL. 51 \& 52)

There is a superordinate and subordinate relationship between words drink and whiskey. However, there is no basic level involved, because it hasn't mentioned that whiskey was a type of aperitif beverage.

\section{General Word}

The last part of reiteration is general word. General word, which correspond to major classes of lexical items, are very commonly used with cohesive force. Not all general words are used cohesively; in fact, only the noun is cohesive in the context of reference. When it has the same referent as whatever it is presupposing, and when it is accompanied by a reference item (Halliday and Hasan, 1976). 
For example:

(11) Walking in the city, we seldom turn and look back. The habit restrained Blake. (P. 2/CL.12\&13)

'Turn and look back' and 'The habit' are classified as general words, because the habit refers to turn and look back. The function is to make the sentence more interesting and not boring.

\section{Collocation}

The concept of collocation is a group of two or more words that are commonly-used together. A collocation is considered "correct" only because its use has been widely-accepted by native English speakers. And according to McCarthy and O'Dell (2005) collocation is divided into several types, which are (a) adjectives and nouns, (b) noun and verb or verb and noun, (c) noun and noun, (d) verb and expression with preposition, (e) verb and adverb and (f) adverb and adjective.

Based on the data, the frequency of collocation is 24 words in which all the elements were found except for verb and expression with preposition and adverb and adjective.

a. Adjective and Noun

For example:

(12) All he could think of to do then was to wait for his heart to stop its hysterical beating, so that he could judge the extent of his danger. (P. 22/CL. 95)

Hysterical is an adjective and Heart is a noun. The use of hysterical in sentence adjacent to heart creates collocation.

\section{b. Verb and Noun}

For example:

(13) The knowledge that his feet were beginning to get wet and that he might catch cold. (P.3/CL.28)

The collocation ties are catch and cold because the words are fixed combinations. In the text, this collocation shows that he has a cold. And it is unusual to say catch flu. So, catch and cold gives cohesive effect.

c. Noun and Noun

For example:

(14) He had quarrelled with his wife, but so did every other man born of woman. It was human nature. (P.13/CL.73)

Human is a noun and Nature is a noun as well. The use of human in sentence adjacent to nature creates collocation.

d. Verb and Adverb

For example:

(15) He heard from off the dark river the drone of an outboard motor, a sound that drew slowly behind. (P.38/CL.151)

Verb and adverb collocation indicated by word drew (verb) and slowly (adverb)

\section{CONCLUSION}

The results of the analysis of the data indicate that all the types of Lexical Cohesion were found in the short story The Five Forty-Eight, with 216 total words frequency. Based on the data, the most dominant type of Lexical Cohesion that appeared is Repetition with 127 data, followed by General Word with 37 data, Collocation with 24 data, Synonym with 16 data and Superordinate with 12 data. The three most commonly used devices are repetition, general word and collocation, which indicates that the author wanted to emphasize setting, highlight a character trait, and draw attention to a seemingly minor detail by using repetition. Then general word by presupposing noun to another word that has the same reference or when it is accompanied by a reference item in order to compose paragraphs cohesively. And the last is collocation to make the language in the short story seemed natural and idiomatic.

Therefore, the analysis results have finally answered all the research question by finding out all the types of lexical cohesion in the short story The Five Forty- 
Eight and also explain what is the role/contribution of lexical cohesion devices in establishing coherence in the short story.

\section{BIBLIOGRAPHY}

Bowen, Glenn. 2009. Document Analysis as a Qualitative Research Method. Qualitative Research Journal, Vol. 9, No. 2.

Cheever, John. 1978. The Stories of John Cheever. United States: Alfred A. Knopf.

Croft, W., \& Cruse, D. A. 2004. Cognitive Linguistics. Cambridge: Cambridge University Press.

Dilla, Frisca, Morelent, Yetty. Gusnetti. Tanpa Tahun. Kohesi Leksikal Dalam Novel HUJAN Karya Tere Liye. Sumatra Barat: Universitas Bung Hatta.

Dwiyatmoko, Benedictus. 2019. Life And Death In Andersen's "Grandmother": A Systemic Functional Grammar Analysis. Jurnal Kata: Penelitian Tentang Ilmu Bahasa dan Sastra, Vol.3 No.1.

Halliday, MAK. Hasan, Ruqaiya. 1976. Cohesion In English. London: Longman Group Limited.

Irawan, Dyah. 2013. TYPES OF LEXICAL COHESION FOUND IN LYRIC OF THE SCRIPTS SONG. Bali: Udayana University.

Keraf, Gorys. 2006. Diksi dan Gaya Bahasa. Jakarta: PT Gramedia Pustaka Utama.

Liyana, Irna. 2014. COHESION AND COHERENCE IN ENGLISH EDUCATION STUDENTS. Journal of Language: Education and Humanities, Vol.1 No.2.

Lucid, Cupid. 2008. Cohesion in English. Pakistan: The Islamia University Bahawalpur.

Luduena, Nare. 2020. Systemic Functional Grammar by Michael Halliday, Accessed from https://www.youtube.com/watch?v
$=\mathrm{j}$-tqkk0IdXU\&list $=$ LL\&index $=28$

on March 11 $1^{\text {th, }} 2021$.

McCarthy, Michael and O'Dell, Felicity. 2005. English Collocations In Use. Cambridge: Cambridge University Press.

McCarthy, Michael. 1991. Discourse Analysis for Language Teachers. Cambridge: Cambridge University Press.

Muhaimi, L. 1997. A Study Cohesion in Analytical Essays of Advanced EFL Students in Lombok. Unpublished Master Thesis.

Muhaimi, L. 2011. Pragmatic Markers in Henry James's Written Narrative The Figure in The Carpet: A Systemic Functional Grammar Analysis. Unpublished Master Thesis.

Mulyana. 2005. Kajian Wacana: Teori, Metode, dan Aplikasi Prinsip Analisis Wacana. Yogyakarta: Tiara Wicana.

Ngogo, Magdalena. 2015. Analisis Kohesi Gramatikal Dan Leksikal Teks Lisan Peminangan Dalam Bahasa Waijewa. Jurnal Tutur, Vol.1, No.2, 1-4.

Paltridge, Brian. 1987. Discourse Analysis: An Introduction. British: British Library Cataloguing-inPublication Data.

Purnomo, Agus. 2013. LEXICAL COHESION ANALYSIS. Jakarta: Islamic University Syarif Hidayatullah.

R. P, Weber. 1990. Basic Content Analysis. Newbury Park, Cal.: Sage.

Situmorang, Rolah. 2014. Jenis Kohesi Leksikal dalam Novel Memang Jodoh Karya Marah Rusli. Jurnal Pendidikan dan Pembelajaran Untan. 1-5.

Sukur, Goridus. 2012. An Analysis Of Lexical Cohesion Used in Embarrassing Short Stories: One Night With A Maid By Sylvester. 


$$
\begin{aligned}
& \text { Malang: University of } \\
& \text { Muhammadiyah Malang. }
\end{aligned}
$$

Tarigan, Henry Guntur. 1987. Membaca Sebagai Suatu Keterampilan Berbahasa. Bandung: Angkasa.

Ulya, Nurul. 2017. An Analysis Of Lexical Cohesion in John Cheever's The Five-Forty Eight. Jakarta: Islamic University Syarif Hidayatullah.

Widayat, Yustinus. 2006. A Tenor Analysis Of Short Story Entitled Cat in The Rain by Ernest Hemingway (A Study Based On Systemic Functional Linguistics). Surakarta: Sebelas Maret University.

Wiratno, Tri. 2018. Pengantar Ringkas Linguistik Sistemik Fungsional. Yogyakarta: Pustaka Pelajar. 